\title{
SAMFUNDSSANKTIONER I ISLAND
}

\author{
AF PROFESSOR RAGNHEIDUR BRAGADÓTTIR
}

\begin{abstract}
During the last decade, three new sanctions were introduced to the Icelandic criminal justice system, which in some cases replace imprisonment. These are alcohol and drug treatment during sentences of imprisonment in closed institutions, sentences of imprisonment and probation in open institutions, and community service. This article describes the laws regarding these sanctions and discusses their application. An unusual aspect of community service in Iceland is that it is the prison administration, as opposed to a judge, that decides whether a convict gets community service. This is criticized since it is revealed that sanctions for certain types of offences have changed without the legislative assembly or the courts having had any influence in the matter.*
\end{abstract}

\section{Indledning}

Den debat, som i 70'erne blev ført i de nordiske lande omkring sanktionssystemet og nye sanktionsformer som alternativ til ubetinget frihedsstraf, blev kun i begrænset grad ført i Island. Det kan til dels forklares ved, at i Island anvendtes fængselsstraf i mindre grad end i nabolandene, og at straffe har været kortere. Derfor er det samme behov for at begrænse anvendelsen af ubetinget frihedsstraf ikke opstået. Inden for sanktionssystemet i Island er der dog alligevel indført tre nye elementer inden for de sidste ti år. Det har ført til, at afsoning af ubetinget frihedsstraf i fængsel er mindsket. De tre elementer er: alkohol- og narkotikabehandling under afsoningen; afsoning af frihedsstraf og vilkårstilsyn hos foreningen "Vernd"; samfundstjeneste. Disse nye sanktions- og afsoningsformer har haft stor betydning i retning af at begrænse antallet af fanger og at forkorte afsoningstiden i fængsel. Der er dog også andre faktorer, der har medvirket hertil, såsom færre domme. I 1996 har 317 fanger afsluttet afsoning, i 1997 var tallet 223, i 1998174 og i 1999157.

\section{Afsoning af straf uden for fængslet}

I § 11 i lov nr. 48/1988, om fængsler og fængselsophold, er der en lovhjemmel til afsoning af straf uden for fængslet. Af $\S 11$, stk. 1, fremgår, at Statens fængselsdirektorat kan tillade at den dømte i en periode eller under hele afsoningen indlægges på sygehus eller anden institution, hvor vedkommende får særlig behandling eller omsorg, eftersom hensynet til hans helbred, alder eller andre særlige omstændigheder nødvendiggør dette. Alkohol- og narkotikabehandling under afsoning af frihedsstraf bygger på denne hjemmel. Da man i 1995 indled-

\footnotetext{
* Title in English: Community Sanctions in Iceland. Original in Danish.
} 
te afsoning på "Vernds" hjem, byggede man også på denne hjemmel. Senere fandt man grund til at lovfæste en mere specifik hjemmel til denne løsning og tilføjede derfor, med lov nr. 22/1999, et nyt stk. 2 til $§ 11$ i lov om fængsler og fængselsophold. Deraf fremgår, at Statens fængselsdirektorat kan give en fange mulighed for at afslutte afsoning uden for fængslet, såfremt han udfører et arbejde eller er under en uddannelse, godkendt af Statens fængselsdirektorat, bor på en særlig institution eller på et hjem, hvor han er under tilsyn, og hvor arbejdet eller uddannelsen er en del af hans resocialisering.

\section{Alkohol-og narkotikabehandling under afsoning af frihedsstraf}

Statens fængselsdirektorat indgik i1990 en aftale med SÁ $\dot{A}^{2}$ om at give en del af fangerne mulighed for at afsone de sidste uger af deres frihedsstraf $i$ alkohol- og narkotikabehandling på SÁÁ's behandlingsinstitutioner. De, der bevilges afsoning $\mathrm{i}$ behandling, afslutter som regel en længere straf, og behandlingen sker ofte i forbindelse med en prøveløsladelse med vilkår og med henblik på bedre at forberede fangen på livet efter afsoningen. Fanger, som gerne vil afslutte afsoningen i behandling, skal skriftligt ansøge om det til Fængselsdirektoratet, som bevilger dette i samråd med SÁÁs overlæge. Ved vurdering af, hvorvidt behandlingen skal bevilges, ses der bl.a. på fangens opførsel under afsoning og andre forhold, som kan give et fingerpeg om, hvorvidt vedkommende er motiveret til at få styr på sit problem. Fængselsdirektoratets beslutning kan appelleres til justitsministeren med en forvaltningskære. I de tilfælde, hvor behandlingen bevilges, underskrives der en aftale mellem Fængselsdirektoratet og fangen. Der sættes bestemte vilkår for behandlingen, og direktoratet afgør i samråd med SÁÁ's overlæge, hvornår behandlingen begynder. Fangen vil så afsone frihedsstraffens sidste 6 uger i behandling. Hvis fangen forlader behandlingsinstitutionen uden Fængselsdirektoratets viden eller samtykke, anses det som undvigelse, der kan straffes med disciplinærstraf. Hvis han overtræder vilkårene for opholdet eller afbryder behandlingen, skal han afslutte afsoningen i fængsel.

Tabel 1. Antal afsonere i behandling hos SAÁ, 1990 - 1999, fordelt efter om behandlingen er afsluttet eller ej.

\begin{tabular}{|l|l|l|l|l|l|l|l|l|l|l|}
\hline & 1990 & 1991 & 1992 & 1993 & 1994 & 1995 & 1996 & 1997 & 1998 & 1999 \\
\hline Afsluttet behandling & 11 & 10 & 7 & 7 & 12 & 20 & 32 & 20 & 13 & 17 \\
\hline Ikke afsluttet behandling & 2 & 6 & 6 & 1 & 2 & 5 & 9 & 10 & 5 & 8 \\
\hline Afsoner i behandling i alt & 13 & 16 & 13 & 8 & 14 & 25 & 41 & 30 & 18 & 25 \\
\hline
\end{tabular}

Det fremgår af tabel 1, at i gennemsnit har 3 ud af 4 afsluttet behandlingen ${ }^{3}$. Året 1999 indførte man den nyhed, at unge dømte blev tilbudt behandling i begyndelsen af afsoning. Dermed steg antallet af dømte, som fik lov til at afsone i behandling, fra 18 i 1998, da det samlede antal fanger, der afsluttede afso- 
ning, var 174, til 25 i 1999, da det samlede fangetal var endnu lavere, nemlig 157. Fra 1990 til 1996 var 54\% af de fanger, der var i behandling, dømt for berigelsesforbrydelser, hvilket svarer til den andel, der idømmes ubetinget fængselsstraf for berigelseskriminalitet i Island. $17 \%$ af dem i behandling var dømt for overtrædelse af færdselsloven, og $29 \%$ for volds- og seksualforbrydelser. Sidstnævnte tyder på en overrepræsentation af volds- og seksualforbrydere $\mathrm{i}$ behandling, idet de kun udgjorde $16 \%$ af strafafsonerne i $1996^{4}$.

\section{Afsoning af frihedsstraf og vilkairstilsyn hos foreningen "Vernd"}

I slutningen af 1994 indgik Fængselsdirektoratet og foreningen "Vernd" en serviceaftale om anbringelse af dømte på hjem hos "Vernd". To grupper af dømte kan få ophold hos "Vernd". Det er for det første personer, der har fået længere domme, og som har afsonet en del af dommen og udvist god opførsel under afsoningen. For det andet drejer det sig om personer, der er blevet idømt kortere domme, har fast arbejde eller er under uddannelse, og som kun har afsonet kort tid. Bestemte vilkår sættes for afsoning hos "Vernd". Afsoningen må ikke gå imod almenhedens interesser. Den dømte må have et godkendt arbejde eller være under uddannelse under afsoningen hos "Vernd", overholde aftaler om mødetider på institutionen, være totalt afholdende mht. alkohol og narkotika, ikke have uafgjorte sager kørende i retssystemet, og afsoningens sluttidspunkt skal være nogenlunde klart, dvs. man ved om/hvornår den dømte skal prøveløslades. I Fængselsdirektoratets bestemmelser om afsoning på "Vernds" hjem, som var gældende indtil oktober 1999, var vilkårene for ophold mere strenge. Ifølge dem havde de, der afsonede frihedsstraf for alvorlige forbrydelser, f.eks. manddrab, volds- eller seksualforbrydelser, større narkotikaforbrydelser, røverier eller andre forbrydelser af særlig grov karakter, ikke mulighed for afsoning hos "Vernd".

Fanger, som ønsker at afsone hos "Vernd", ansøger herom hos Fængselsdirektoratet, som foretager en vurdering af, om betingelserne er opfyldt. Ansøgninger om ophold forelægges "Vernds" husnævn, som afdelingschefen hos Fængselsdirektoratet har sæde i. Både Fængselsdirektoratet og "Vernd" skal godkende opholdet. Hvis Fængselsdirektoratet afviser en ansøgning, kan afgørelsen appelleres til Justitsministeriet. Hvis husnævnet til gengæld vurderer, at ansøgeren ikke er egnet til afsoning hos "Vernd", er den afgørelse endelig. Udgifter i forbindelse med ophold hos "Vernd" afholdes af den dømte. Tilsyn med de dømte varetages først og fremmest af "Vernds" personale, men også af Fængselsdirektoratet. De dømte skal følge "Vernds" husreglement. Det er ikke tilladt at være hjemmefra mellem klokken $23 \mathrm{om}$ aftenen til klokken $7 \mathrm{om}$ morgenen, og fravær efter klokken 18 er ikke tilladt i weekenden. Hvis den dømte overtræder Fængselsdirektoratets vilkår, "Vernds" husreglement eller begår en ny forbrydelse, kan Fængselsdirektoratet bringe ham til afsoning i fængsel og give ham disciplinærstraf. 
De, der bevilges ophold hos "Vernd", har alle afsonet en del af frihedsstraffen i fængsel. Fængselsdirektoratets regler om afsoning på hjemmet siger, at en fange skal have afsonet mindst $1 / 3$ del af straffen i fængsel, inden han får mulighed for afsoning hos "Vernd". Maksimal afsoningstid hos "Vernd" er 6 måneder.

Tabel 2. Antal bevilgede afsoninger hos "Vernd", 1995 - 1999, fordelt efter om vilkårene er overholdt eller overtrådt. ${ }^{5}$

\begin{tabular}{|l|l|l|l|l|l|}
\hline & 1995 & 1996 & 1997 & 1998 & 1999 \\
\hline Overholdt vilkår for ophold & 28 & 55 & 38 & 34 & 33 \\
\hline Vendt tilbage til fængsel & 3 & 5 & 5 & 8 & 14 \\
\hline Antal bevilgede afsoninger i alt & 31 & 60 & 43 & 42 & 47 \\
\hline
\end{tabular}

Som man kan se af tabel 2, fik 31 fanger bevilget ophold hos "Vernd" i 1995. Man var dengang forsigtig med at anvende denne løsning, men da der var gode resultater hermed, voksede antallet af dømte som afsonede hos "Vernd" betydeligt i 1996. Året 1997 blev gruppen mindre, eftersom færre var i fængsel som følge af samfundstjenesteordningen. Ingen af vilkårsovertrædelserne medførte politiets indblanding.

\section{Samfundstjeneste}

Samfundstjeneste blev indført som forsøgsordning ved lov nr. 55/1994. Loven, der trådte $\mathrm{i}$ kraft den 1. juli 1995, var midlertidig og havde gyldighed indtil.den 31. december 1997. Ifølge loven var der hjemmel til at fuldbyrde op til 3 måneders ubetinget frihedsstraf ved udførelse af samfundstjeneste, mindst 40 timer og højst 120 timer, i henhold til bestemte vilkår. Et trepersoners udvalg, nedsat af justitsministeren, afgjorde, hvorvidt fuldbyrdelse ved samfundstjeneste kunne bevilges. Udvalgets afgørelser var endelige. Mens loven havde gyldighed, blev omkring $40 \%$ af de ubetingede frihedsstraffe på tre måneder eller derunder fuldbyrdet med samfundstjeneste.

Forsøget med samfundstjeneste var utvivlsomt vellykket, og man fandt derfor grund til at lovfæste ordningen og gøre den permanent. Det blev besluttet at indføre bestemmelser herom i lov om fængsler og fængselsophold nr. 48/1988, med den begrundelse, at denne ordning er en måde at fuldbyrde en ubetinget frihedsstraf på, hvorfor den hører hjemme i samme lov som andre bestemmelser om fuldbyrdelse af ubetinget frihedsstraf. I $1999 \mathrm{blev}$ der endvidere, jfr. lov nr. $22 / 1999$, tilføjet bestemmelser om samfundstjeneste som fuldbyrdelse af forvandlingsstraf.

\section{Samfundstjeneste som alternativ til fuldbyrdelse af ubetinget fangselsstraf}

A. Hvornår kan en dom fuldbyrdes ved samfundstjeneste?

Der er hjemmel til at fuldbyrde op til 6 måneders ubetinget fængsel med ulønnet 
samfundstjeneste, mindst 40 timer og højst 240 timer, jfr. § 22, lov nr. 48/1988 om fængsler og fængselsophold, jfr. § 4, lov nr. 123/1997. Hvis frihedsstraf fuldbyrdes for mere end én dom, kan den samlede straf ikke overstige seks måneders fængsel, jfr. § 22, stk. 2. Hvis det drejer sig om en kombinationsdom, kan den ubetingede del fuldbyrdes med samfundstjeneste, hvis den samlede straf ikke overstiger seks måneders fængsel, jfr. § 22, stk. 3. I henhold til § 23, stk. 3, er 40 timers samfundstjeneste lig med en måneds fængselsstraf. Der er ikke hjemmel til at fuldbyrde straf ved samfundstjeneste, hvis det strider mod almenhedens interesse, jfr. $\S 22$, stk. 1, eftersom samfundstjeneste ikke må svække straffens almenpræventive virkning. Den kan især komme på tale, hvor specialpræventive formål har betydning for strafudmålingen, f.eks. ved berigelsesforbrydelse og dokumentfalsk.

\section{B. Forudsætninger for fuldbyrdelse af dom ved samfundstjeneste}

Forudsætninger for at fuldbyrde en dom ved samfundstjeneste anføres i $\S 23$, stk. 1, i lov nr. 48/1988, jfr. § 4 , lov nr. 123/1997. Den dømte skal for det første skriftligt ansøge om samfundstjeneste hos Fængselsdirektoratet senest fjorten dage før, afsoning af frihedsstraf skulle påbegyndes. De dømte, som opfylder lovens objektive forudsætninger, tilsendes information om samfundstjeneste og ansøgningsformularer samtidig med indkaldelse til afsoning. For det andet må den dømte ikke have uafsluttede sager vedrørende strafbare forhold. For det tredje skal den dømte vurderes egnet til samfundstjeneste. Ved vurdering heraf tages der hensyn til personlige forhold og tidligere kriminalitet. Mange dømte har problemer på grund af alkohol- eller narkotikamisbrug. Det skal vurderes, om det problem står i vejen for muligheden for at gennemføre samfundstjeneste. Sandsynligheden for, at samfundstjeneste kan føre til, at den dømte vil forlade den kriminelle bane, skal også vurderes. Tidligere begået kriminalitet kan give et fingerpeg herom. Hvis en person ofte har afsonet frihedsstraf, er det usandsynligt at han kan yde samfundstjeneste. Det skal dog vurderes i hvert enkelt tilfælde, eftersom personens forhold kan have ændret sig. Forbrydelsens karakter har også betydning, idet samfundstjeneste forholdsvis sjældent bevilges til personer, der er dømt for narkotikakriminalitet, hærværk eller vold.

Det findes hjemmel til at fravige tidsfrister mht. ansøgning om samfundstjeneste, hvis der er specielle grunde til, at den dømte ikke har kunnet indgive sin ansøgning i tide. Med lov nr. 22/1999, indførtes muligheden for at dispensere fra vilkåret om, at den dømte ikke må have sager under behandling i retssystemet, hvis særlige forhold taler derfor.

\section{Fængselsdirektoratet træffer afgørelsen om samfundstjeneste}

Fængselsdirektoratet træffer afgørelsen om samfundstjeneste på samme måde, som det gør om orlov fra afsoning, prøveløsladelse og afsoningssted. Direktora- 
tet afgør desuden, hvilket arbejde den dømte skal udføre, og over hvor lang tid, det skal udføres. Den tid kan dog aldrig blive kortere end to måneder, jfr. § 24, stk. 1. Det forudsættes, at arbejdspligten fordeles ligeligt over perioden, og Fængselsdirektoratet afgør, hvilke dage og hvilken tid på dagen arbejdet skal udføres. Mindstetiden på to måneder er begrundet $\mathrm{i}$, at samfundstjenestens pædagogiske virkning ikke kan opnås, hvis arbejdet afsluttes på for kort tid. Behandling af ansøgninger om samfundstjeneste udsætter frihedsstraffens fuldbyrdelse, indtil afgørelse foreligger. Det er dog en forudsætning, at den dømte ikke begår strafbar handling, mens hans sag er under behandling, jfr. § 24, stk. 3, lov nr. 48/1988.

\section{Appel til justitsministeren}

Fængselsdirektoratets afgørelser om samfundstjeneste kan appelleres til justitsministeren, som træffer den endelige afgørelse efter indstilling fra benådningsudvalget. Det er et udvalg på tre personer, udpeget af justitsministeren, jfr. bekendtgørelse nr. 29, fra 1993, om fuldbyrdelse af straffedomme. Udvalget har hidtil haft til opgave at afgive motiverede indstillinger til ministeren vedrørende appellerede ansøgninger om prøveløsladelse og benådningsansøgninger.

Med $\S 5$ i lov nr. 123/1997, blev der imidlertid lovfæstet en bestemmelse i $\S$ 32, lov nr. 48/1988, om, at udvalget nu også skal give ministeren et motiveret forslag om behandling af sager om samfundstjeneste. Denne appelmulighed er gennemført med henblik på at skabe større retssikkerhed for den dømte.

\section{E. Vilkår for samfundstjeneste}

I § 25 i lov nr. 48/1988, anføres de to vilkår, som altid skal gives for samfundstjeneste. For det første må den dømte ikke gøre sig skyldig i strafbar handling i løbet af den tid, samfundstjenesten udføres. For det andet skal han være under tilsyn og kontrol af en person, en forening eller institution i den tid, han fuldbyrder sin dom ved samfundstjeneste. Desuden er der hjemmel til at give de vilkår, der kan gives i forbindelse med en betinget dom, jfr. straffelovens $\S 57$, stk. 3 , 2.-6. Disse vilkår vedrører forskrifter om opholdssted, uddannelse, arbejde, samkvem med andre, fritidsbeskæftigelse, afhold fra brug af alkohol og narkotika, ophold på en særlig institution til afvænningsbehandling for misbrug af alkohol eller narkotika i op til 18 måneder, indskrænkninger i rådighed over indtægter og andre økonomiske forhold samt udbedring af skader, der er forvoldt ved forbrydelsen.

\section{F. Overtrædelse af vilkårene for samfundstjeneste}

Hvis den dømte overtræder vilkårene for prøveløsladelsen ved at begå en ny forbrydelse under prøvetiden, er det domstolene, og ikke forvaltningen, som afgør, 
om resten af straffen skal indgå i fællesstraf, og om denne straf skal gøres betinget eller ubetinget, jfr. $\S 42$ i straffeloven. Anderledes forholder det sig i tilfælde af overtrædelse af vilkår for samfundstjeneste. Sagsbehandlingen på dette område er tilpasset den ordning, som gælder sagsbehandlingen for disciplinærforseelser i fængsler, således at Fængselsdirektoratet men ikke domstolene har den afgørende magt, når vilkårene for samfundstjeneste overtrædes. Det er i overensstemmelse med lovens formål, at fuldbyrdelsen af ubetinget frihedsstraf ved samfundstjeneste så vidt muligt svarer til anden fuldbyrdelse af ubetingede domme.

I $\S 26$, lov nr. 48/1988, fastsættes, hvordan der skal reageres, hvis den dømte overtræder vilkårene for samfundstjeneste. I stk. 1 anføres, at hvis den dømte overtræder vilkårene eller ikke udfører samfundstjenesten på tilfredsstillende måde, afgør Fængselsdirektoratet, om vilkårene skal ændres, om den tid, hvori samfundstjenesten udføres, skal forlænges, eller om dommen skal afsones i fængsel. I betænkningen til lovforslaget anføres, at det er nødvendigt straks at gribe ind over for vilkårsovertrædelser, hvis den pædagogiske målsætning - at understrege over for den dømte, at han skal yde samfundstjenesten samvittighedsfuldt og oprigtigt - skal opnås .

I § 26, stk. 2, fastsættes reaktioner i tilfælde af ny kriminalitet, dvs. sigtelse for at have begået strafbar handling efter at beslutningen om at fuldbyrde dommen ved samfundstjeneste er truffet. Fængselsdirektoratet kan i så tilfælde tilbagekalde afgørelsen og beslutte, at den dømte skal afsone frihedsstraffen. Det er derfor klart, at det ikke er hensigten, at den domstol, som behandler den nye forbrydelse, skal genoptage den tidligere sag og fastsætte samlet straf for begge forbrydelser, jfr. $\S 42$, stk. 1, og $\S 60$ i straffeloven?

Hvis en vilkårsovertrædelse eller en nye forbrydelse ikke er alvorlig eller gentager sig, får den dømte en advarsel, i stedet for at afsone frihedsstraffen, jfr. $\S 26$, stk. 3. I betænkningen til lovforslaget nævnes som eksempel på mindre alvorlige vilkårsovertrædelser, at den dømte kommer nogen minutter for sent til arbejde, og som eksempel på mindre alvorlige lovovertrædelse nævnes overtrædelse af hastighedsbestemmelser og vigepligten ${ }^{8}$.

Hvis det besluttes, at frihedsstraffen skal afsones, fradrages den del af straffen, den dømte allerede har afsonet ved samfundstjeneste, jfr. § 26, stk. 4.

I § 26, stk. 5, er der en bestemmelse om bevilling af prøveløsladelse i forannævnte tilfælde, idet det fremgår, at den del af straffen, der er afsonet ved samfundstjeneste, ikke indgår i beregningen af tidspunktet for eventuel prøveløsladelse. 
Tabel 3. Antal straffuldbyrdelser ved samfundstjeneste, 1995 -1999, fordelt efter om vilkår er overtrådt eller ej.

\begin{tabular}{|l|l|l|l|l|l|}
\hline & 1995 & 1996 & 1997 & 1998 & 1999 \\
\hline Uden vilkårsovertrædelser & 6 & 50 & 41 & 64 & 50 \\
\hline Med vilkårsovertrædelser & 1 & 2 & 7 & $7^{9}$ & 11 \\
\hline Afsluttet samfundstjeneste i alt & 7 & 52 & 48 & 71 & 61 \\
\hline
\end{tabular}

En ny rapport om recidiv viser, at efter 3 år var $17 \%$ af dem, som afsonede ved samfundstjeneste, blevet fængslet igen, i alt $22 \%$ havde fået en ny dom, og i alt $55 \%$ var blevet anmeldt til politiet. ${ }^{10}$ De tilsvarende tal for dem, som afsonede fængselsstraf, var henholdsvis $29 \%, 38 \%$ og $67 \%{ }^{11}$. Det skal dog understreges, at de, der afsoner ved samfundstjeneste, adskiller sig fra dem, som afsoner i fængsel, ved gennemgående at være ældre, have færre tidligere domme og være dømt for mindre alvorlig kriminalitet.

\section{Fuldbyrdelse af forvandlingsstraf med samfundstjeneste}

Den 1. januar 2000 er ikrafttrædelsesdatoen for lov nr. 22/1999, om ændring af lov om fængsler og fængselsophold nr. 48/1988. Med denne lov fik fængselsloven tilføjet et afsnit om fuldbyrdelse af forvandlingsstraf ved samfundstjeneste. Bestemmelserne blev indført for at imødegå skævheder mellem afsonere af frihedsstraf og afsonere af bødeforvandlingsstraf, idet de hidtidige regler ikke havde givet sidstnævnte gruppe mulighed for at afsone ved samfundstjeneste.

\section{A. Bøde og forvandlingsstraf}

I straffelovens $\S 53$ er der en bestemmelse om bøder. Der anføres den hovedregel, at hvis bøden ikke betales, skal fængsel træde i stedet. En undtagelse er dog de tilfælde, hvor hverken forsæt eller uagtsomhed foreligger. Der findes hjemmel til at inddrive bøder ved udpantning, jfr. straffelovens $\S 52$, og på den måde effektueres straffen for dem, der kan, men ikke vil betale. Tilbage står så de ubemidlede, som kommer til at afsone bødens forvandlingsstraf, dvs. i fængsel. Denne konsekvens kan kritiseres, da de dømte hermed diskrimineres på baggrund af deres økonomiske formåen.

I bemærkninger til lov nr. 22/1999, gøres der opmærksom på, hvor belastende det er for en person, som er idømt en bøde, at skulle afsone bøde med forvandlingsstraf i fængsel, eftersom bøder er den mildeste straf. Der er også uoverensstemmelse mellem det forhold, at en person, som er idømt ubetinget frihedsstraf, kan fuldbyrde straffen ved samfundstjeneste, mens en person, som har fået en mildere straf, dvs. bødestraf, skal afsone i fængsel, hvis ikke han kan betale bøden. Derfor blev der med denne lov lovfæstet en mulighed at en bøde kan fuldbyrdes på en anden måde end med frihedsstraf, dvs. ved samfundstjeneste. 
Fængslet skal dog stadigvæk anvendes som forvandlingsstraf, hvis den dømte ikke overholder samfundstjenestens vilkår eller ikke udfører den. ${ }^{12}$

Her bør man også tænke på, at antallet af domme, som fastsætter meget store bøder, er vokset i løbet af de sidste år, ikke mindst i forbindelse med forskellige former for skatteforbrydelser i kølvandet på en ændring af strafferammen herfor i 1995. Bøder har ofte været så store, at den maksimale forvandlingsstraf, et års fængsel, er udmålt. Det er værd at overveje, om domme for formuekrænkelser og økonomiske forbrydelser af forskellig art ikke er blevet for høje, ikke mindst med tanke på, at domme for traditionelle berigelsesforbrydelser er betydelig mildere. De dømte, der ofte har mistet alt og er gået konkurs, kan på ingen måde betale de store bøder og har derfor måttet afsone i fængsel. Desuden har man ment, at de ikke skal have mulighed for prøveløsladelse i lighed med dem, der afsoner frihedsstraf, eftersom straffelovens bestemmelser om prøveløsladelse er blevet tolket således, at de udelukkende gælder frihedsstraf, men ikke bødeforvandlingsstraf. For at fjerne al tvivl er den fortolkning, at de ikke kan prøveløslades, nu blevet lovfæstet i straffelovens $\S 40$, jfr. lov nr. 24/1999. Det er derfor naturligt at gøre disse dømtes forhold nemmere, ved at gøre det muligt for dem at fyldbyrde domme med samfundstjeneste.

\section{B. Hvornår kan forvandlingsstraf fuldbyrdes med samfundstjeneste?}

I $\S 26$ a i lov nr. $48 / 1988$, jfr. § 5, lov nr. 22/1999, siges, at hvis politimesteren har besluttet, at en person skal afsone bødeforvandlingsstraf, er der hjemmel for, hvis ikke det går imod almenhedens interesse, at fuldbyrde forvandlingsstraffen med ulønnet samfundstjeneste. Mindstetiden er 20 timer og længstetiden 480 timer. Her er samfundstjenestens timeantal mere rummeligt, end tilfældet er for samfundstjeneste i forbindelse med en ubetinget frihedsstraf. I betænkningen til lovforslaget siges, at det af hensyn til straffens præventive virkning og formålet med samfundstjeneste er nødvendigt at fastsætte mindstetimetallet til 20 timer, på trods af at forvandlingsstraffens længde er mindre end 15 dages fængsel ${ }^{13}$ og trods reglen om, at 40 timers samfundstjeneste svarer til én måneds fængsel. Den maksimale forvandlingsstraf på ét år skal fuldbyrdes med 480 timers samfundstjeneste. I betænkningen anføres, at det ikke er utilrådeligt at give hjemmel til fuldbyrdelse af et års forvandlingsstraf med samfundstjeneste, selvom den maksimale straf, som kan fuldbyrdes på den måde, er seks måneders fængsel. Det beror på, at bøder altid er en mildere straf end ubetinget fængsel ${ }^{14}$.

Hvis en person er blevet idømt både ubetinget fængsel og en bøde, er det ikke muligt at fuldbyrde forvandlingsstraffen med samfundstjeneste i de tilfælde, hvor den sammenlagte fængselsstraf og forvandlingsstraf overstiger ét år. Det har i denne forbindelse ingen betydning, om straffene er idømt samtidig eller på forskellige tidspunkter. Det samme gør sig gældende, når der samtidig fuldbyr- 
des forvandlingsstraf for flere bøder. Hvis summen af bødeforvandlingsstraffe og eventuel ubetinget frihedsstraf overstiger ét år, er der altså ikke hjemmel til at fuldbyrde forvandlingsstraffen med samfundstjeneste. Her må det bemærkes, at den ubetingede frihedsstrafs andel aldrig kan overstige seks måneder.

\section{Vilkår og behandling}

I henhold til $\S 26 \mathrm{~b}$ anvendes bestemmelserne fra fængselslovens $\S \S 23-26$ vedrørende betingelserne for samfundstjeneste. Reglerne om Fængselsdirektoratets behandling af ansøgninger om samfundstjeneste og om vilkår for samfundstjeneste gælder også for forvandlingsstraffe. I stedet for at indsende ansøgning om samfundstjeneste til Fængselsdirektoratet skal den dog i tilfælde af forvandlingsstraf sendes til politimesteren, eftersom han tager sig af inddrivelse af bøder, jfr. straffelovens $\S 52$, stk. 2. Politimesteren indsender så ansøgningen sammen med sin indstilling til Fængselsdirektoratet. På denne måde behandler Fængselsdirektoratet samtlige sager angående samfundstjeneste.

\section{Hvem skal afgøre om samfundstjeneste?}

\section{Ifølge islandsk lov er samfundstjeneste en forvaltningsakt}

Det er forvaltningen, der afgør, om samfundstjeneste kan anvendes. Sådan har det været fra begyndelsen. Samfundstjeneste betragtes ikke som en ændring af frihedsstraffen, således at ulønnet samfundstjeneste kan træde i stedet herfor, men der lægges vægt på, at samfundstjeneste er et af de alternativer, myndighederne har mulighed for at anvende i forbindelse med fuldbyrdelse af frihedsstraffe ${ }^{15}$. Denne ordning om afgørelse af samfundstjeneste er enestående og findes ikke andre steder, hvor samfundstjeneste anvendes.

\section{Argumenter for forvaltningsvejen}

I bemærkninger til forslag om lov om samfundstjeneste fra 1994 anføres to argumenter for, at samfundstjeneste skal afgøres af forvaltningen. Det begrundes med, at man "kan forvente, at udgifter ved praksis bliver betydelig lavere, end hvis afgørelsen lægges til domstolene i hvert enkelt tilfælde." For det andet anføres, at hvis denne sanktionsform skal lykkes, er det vigtigt at "have god kontrol over dette eksperiment, så man kan bygge op, udvikle og tilpasse samfundstjenesten forholdene her i landet" ${ }^{\text {" }}$. I bemærkninger til forslag til lov om tilføjelse til straffeloven nr. 19, af 12. februar 1940, som blev fremsat i $1991^{17}$, og som var det første lovforslag om samfundstjeneste, anføres et tredje argument, nemlig at denne ordning er den, der bedst kan sikre, at samfundstjenesten træder i stedet for ubetinget frihedsstraf ${ }^{18}$.

Men holder disse argumenter?

I bemærkningerne er der ingen forklaring på, hvorfor man "kan forvente", at forvaltningsvejen er billigere end domstolsvejen. Det er også svært at se, hvor- 
for det skulle forholde sig på denne måde. Hvis domstolene havde hjemmel til at dømme til samfundstjeneste, ville de fastsætte antal arbejdstimer og afsoningstid. Antal arbejdstimer ville blive fastsat indenfor lovens rammer og ville følge almene bestemmelser og holdninger til straffens fastsættelse. Fængselsdirektoratet ville til gengæld sørge for dommens fuldbyrdelse, ligesom den gør med andre straffedomme. Direktoratet ville både bestemme arbejdsplads, hvornår arbejdsindsatsen skulle ydes og have tilsyn med praksis, hvilket stemmer overens med nugældende regler. Den eneste tænkelige udgiftsforøgelse ville være de tilfælde, hvor domstole fik udarbejdet personundersøgelser om personer, som siden ikke blev idømt samfundstjeneste. Undersøgelserne ville dog under alle omstændigheder kunne udnyttes af domstolene, eftersom den dømtes personlige forhold er en af de faktorer, som der skal tages hensyn til ved straffastsættelsen. Til gengæld ville dommerne ikke få undersøgelser af den art udarbejdet i de tilfælde, hvor det er indlysende, at den tiltalte er uegnet til at udføre samfundstjeneste. Dertil kommer, at det må være mere praktisk, at én part, dvs. domstolene, træffer afgørelsen, i stedet for at domstolene beslutter om fængselsstraf, som forvaltningen siden reviderer.

Men er forvaltningsvejen bedre egnet til at tilpasse samfundstjeneste til forholdene i Island? Som argument herfor har det været fremført, at forholdene i Island på mange måder er forskellige fra dem i vore nabolande. Få mennesker, spredt bebyggelse og moderat brug af ubetinget fængsel er faktorer, som man har anset kunne tale imod anvendelse af samfundstjeneste i Island ${ }^{19}$. Disse forhold har samtidig kunnet tale for, at såfremt samfundstjeneste skulle anvendes, er forvaltningsvejen mest hensigtsmæssig, eftersom man måtte forvente, at samfundstjeneste sjældent ville blive aktuelt i distrikter med få mennesker. I distrikter med få mennesker vil domstolene således ikke opnå kompetence til at dømme i disse sager, da de så sjældent forekommer. Forvaltningsvejen vil derfor bedre kunne sikre ensartethed i sagsbehandlingen, eftersom afgørelser om samfundstjeneste er i hænderne på én part. Denne argument kan man slet ikke acceptere. Selvfølgelig kan domstole dømme i sager som sjældent forekommer. Det er også klart, at selv om den afgørende magt ligger hos domstolene, kan forvaltningen alligevel godt udvikle og tilpasse samfundstjeneste til forholdene i Island. Domstolene ville under alle omstændigheder kun afgøre om antal timer og afsoningstid. Praksis, opbygning og nærmere ordning ville stadigvæk være i Fængselsdirektoratets hænder. Det er også klart, at selv om forvaltningsvejen var hensigtsmæssig i 1994, da samfundstjenesten blev indført som forsøgsordning, gjaldt det ikke nødvendigvis længere i 1997, da samfundstjeneste blev lavet om til permanent alternativ. Der var da blevet oparbejdet erfaring, og samfundstjenesten var blevet tilpasset forholdene her i landet.

Det tredje og sidste argument var, at med forvaltningsvejen kunne man bedst sikre, at samfundstjenesten kom i stedet for ubetinget frihedsstraf. Dette er selvfølgelig rigtigt. Kun ubetinget fængselsstraf kan fuldbyrdes med samfundstjene- 
ste. Hvis domstolen har hjemmel til at anvende samfundstjeneste, er det tænkeligt, at den også anvendes i tilfælde, hvor man ellers havde idømt betinget fængselsstraf. Det ser jeg faktisk mere som en fordel end en ulempe. Den slags anvendelse af samfundstjeneste kan bygge en bro over den brede kløft, som er i mellem betinget og ubetinget fængselsstraf i Island. Samfundstjeneste som vilkår for en betinget dom kunne også gøre den slags domme mere hensigtsmæssige og mere målrettede og dermed give større mulighed for kontrol ${ }^{20}$. Det ville især komme unge kriminelle til gode.

Nogen lægger stor vægt på samfundstjenestens pædagogiske rolle, og det danske straffelovråd har brugt det i sin argumentation for at indføre samfundstjeneste i Danmark. Det arbejde, som udføres i samfundstjeneste, er som regel en slags hjælpe- eller assistentarbejde af betydning for samfundet. Det anses at understøtte dette alternativs pædagogiske formål. Det er dog klart, at samfundstjenestens pædagogiske betydning kun vil gælde de meget unge kriminelle, som ikke er straffet mange gange tidligere. Hvis vi ser på anvendelsen af samfundstjeneste i Island, er det dog klart, at den sjældent vedrører de unge kriminelle. Dette fremgår af tabel 4, som viser aldersfordelingen for dem, som havde afsluttet (evt. afbrudt) samfundstjeneste i løbet af året, eller som var i samfundstjeneste ved årets udgang.

Tabel 4. Antal afsluttede, afbrudte og igangvarende samfundstjenestesanktioner, 1995 -1999, fordelt efter den dømtes alder.

\begin{tabular}{|l|l|l|l|l|l|l|l|l|l|l|}
\hline & \multicolumn{2}{|c|}{1995} & \multicolumn{2}{c|}{1996} & \multicolumn{3}{c|}{1997} & \multicolumn{2}{c|}{1998} & \multicolumn{2}{c|}{1999} \\
\hline Alder & Antal & $\%$ & Antal & $\%$ & Antal & $\%$ & Antal & $\%$ & Antal & $\%$ \\
\hline $16-17$ & 0 & 0,0 & 0 & 0,0 & 0 & 0,0 & 0 & 0,0 & 0 & 0,0 \\
\hline $18-20$ & 1 & 5,0 & 0 & 0,0 & 1 & 1,8 & 6 & 6,6 & 3 & 3,8 \\
\hline $21-25$ & 4 & 20,0 & 10 & 17,2 & 13 & 23,6 & 22 & 24,2 & 25 & 31,6 \\
\hline $26-30$ & 4 & 20,0 & 17 & 29,3 & 10 & 18,2 & 16 & 17,6 & 17 & 21,5 \\
\hline $31-35$ & 6 & 30,0 & 9 & 15,5 & 7 & 12,7 & 14 & 15,4 & 9 & 11,4 \\
\hline $36-40$ & 2 & 10,0 & 7 & 12,1 & 6 & 10,9 & 9 & 9,9 & 5 & 6,3 \\
\hline $41-50$ & 1 & 5,0 & 6 & 10,3 & 14 & 25,5 & 17 & 18,7 & 16 & 20,3 \\
\hline $51-$ & 2 & 10,0 & 9 & 15,5 & 4 & 7,3 & 7 & 7,7 & 4 & 5,1 \\
\hline I alt & 20 & 100,0 & 58 & 100,0 & 55 & 100,0 & 91 & 100,0 & 79 & 100,0 \\
\hline
\end{tabular}

I perioden 1995-1999 var der ingen dømte i alderen 16-17 år i samfundstjeneste. Ved udgangen af 1999 var de fleste i alderen 21-25 år, og der er også mange i alderen 26-30 år og 41-50 år. Hvis domstolene havde hjemmel til at idømme samfundstjeneste, enten som en selvstændig strafart eller som vilkår for betinget dom i stedet for almindelig betinget dom, kunne man holde bedre opsyn med unge kriminelle og muligvis føre nogle af dem væk fra den kriminelle 
bane. Såfremt domstolene traf afgørelsen om samfundstjeneste, ville den endelige afgørelse desuden foreligge tidligere end ellers, hvilket, ikke mindst for unge kriminelle, er meget vigtigt.

Udover disse tre argumenter for forvaltningsvejen, som fremkom i bemærkninger, anføres ofte andre argumenter. Et argument er, at den udøvende magt også på andre måder blander sig i dommene. Den bestemmer, hvor og hvornår frihedsstraffens afsoning foregår. Den kan også tillade prøveløsladelse og benådning. Derfor burde den også kunne tillade samfundstjeneste. Om dette kan man sige, at der er stor forskel mellem på den ene side eftergivelse af en del af frihedsstraffen, som tilfældet er med prøveløsladelse, og på den anden side ændring af fuldbyrdelsesmåden for hele dommen, som tilfældet er med samfundstjeneste. Prøveløsladelse bevilges efter, at den dømte har afsonet en bestemt del af den idømte frihedsstraf, enten halvdelen eller to tredje dele. Han skal opfylde bestemte betingelser for at kunne få prøveløsladelse, som han da får som belønning. Benådning bevilges i særlige undtagelsestilfælde, og kun hvis man anser, at straffens afsoning vil skade den dømtes velfærd. Begrundelsen for benådning er som oftest den dømtes dårlige helbred. Både prøveløsladelse og benådning bygger på, at forholdene har ændret sig siden dommens fastsættelse. Således forholder det sig ikke med samfundstjeneste.

Det er naturligt at have en hjemmel i loven om, at hvis en bøde ikke betales, kan samfundstjeneste indtræde. Det indebærer større retfærdighed og rimelighed. Som anført i betænkningen med forslag til lov nr. 22/1999, er det forkert, hvis de, der idømmes ubetinget fængsel, kan afsone det ved samfundstjeneste, men ikke dem, som har fået en mildere dom, dvs. bødestraf ${ }^{22}$. Men dette rejser samme spørgsmål som tidligere. Hvorfor har domstolene ikke hjemmel til at træffe afgørelsen om samfundstjeneste som bødeforvandlingsstraf?

\section{Hvad er straf?}

Efter min mening er der ingen tvivl om, at samfundstjeneste har karakter af straf og ikke er en ordning til fuldbyrdelse af ubetinget frihedsstraf. Begrebet straf er ikke defineret noget sted i loven. Det knyttes an til begrebet forbrydelse, og defineres i teorien i forbindelse med det begreb, således at straf udelukkende vedrører den adfærd, som beskrives som forbrydelse i gældende lov. I det islandske retssystem er strafarterne fængsel og bøde. Strafbegrebets indhold beskrives som en form for sanktion, statsmagten kan anvende over for den, som er skyldig $i$ en strafbar handling. Straffen udtrykker samfundets fordømmelse og mishag og er egnet til at volde den dømte lidelse eller ubehag ${ }^{23}$. Samfundstjeneste opfylder disse betingelser til fulde, og derfor er det naturligt at lovfæste bestemmelser om den som straf, uanset om den bliver en selvstændig strafart eller som vilkår for betinget dom. 


\section{Domstolen skal idømme straf, men forvaltningen skal tage sig af fuldbyrdel-} sen

Forvaltningsvejen har ført til, at den udøvende magt i realiteten er begyndt at bestemme om sanktioner, som i deres karakter er straf, dvs. i forhold, som indtil nu udelukkende har hørt ind under domstolene. Hvorfor er det ikke i orden? Svaret findes i den islandske grundlovs $\S 2$. Der står, at vores forfatning bygger på statsmagtens tredeling. Det er den lovgivende magts rolle at lovfæste straffebestemmelser og afgøre, hvilken type straf der skal anvendes over for bestemte forbrydelser. Tendensen de sidste år har været, at straffesystemet skal være enkelt og forudsigeligt. Domstolene skal dømme i henhold til loven, i hvert enkelt tilfælde vurdere, hvorvidt der er tale om overtrædelse af bestemte regler, bestemme om sanktioner, herunder straffens art, dvs. fængsel og/eller bøde i henhold til nugældende lov, samt fastsætte straffen inden for den strafferamme, der er sat af den lovgivende magt. Derefter er det den udøvende magts rolle at sørge for disse dommes fuldbyrdelse. Fuldbyrdelsen må nødvendigvis ske i henhold til dommen, dvs. inddrivelse af bøder, sørge for afsoning af den ubetingede fængselsstraf fastsat af domstolen eller sørge for tilsyn eller andre vilkår, som anført i de betingede domme.

Selvom dette er nogenlunde klart, kan grænsen mellem den dømmende magt og forvaltningen ofte være flydende. Således kan den lovgivende magt i visse tilfælde give forvaltningen magt til at omhandle en bestemt retstvist, og forvaltningen har måske også til en vis grad hjemmel til at fastsætte straffe. I lovgivningen findes der derimod ingen almene bestemmelser om, hvilke sager domstolene har magt til at fastsætte. Det er dog klart, at der er grænser for, hvor langt den lovgivende magt kan gå med hensyn til at afgive magt til afgørelse om retstvister til forvaltningen. Ólafur Jóhannesson mener, at den lovgivende magt ikke har hjemmel til at afgive magt til den udøvende myndighed til fastsættelse af straf, eftersom straffastsættelse er "den dømmende myndigheds fundament" ${ }^{\text {"24 }}$. Fastsættelse af straf er domstolens rolle og ikke forvaltningens. Samfundstjeneste er en sanktionsform, som anvendes på grund af forbrydelser og er i sin karakter en straf. Derfor skal samme hovedregel gælde om samfundstjeneste som for straf, dvs. at dommere fastsætter den i form af en dom. På den måde må borgerens retssikkerhed være bedst sikret, uanset det forhold, at forvaltningens nuværende ret til at træffe bestemmelse om fængselsstraffes fuldbyrdelse ved samfundstjeneste er begunstigende for den dømte. Det er indlysende, at sagsbehandlingen hos domstolene er meget bedre end hos forvaltningen. Vi må heller ikke glemme, at hvis den dømtes fuldbyrdelse af samfundstjenesten slår fejl, kan Fængselsdirektoratet tage beslutninger, som er belastende for ham, f.eks. at han afsoner resten af dommen. Det kan diskuteres, om det er i overensstemmelse med $\S 6$, stk. 2 , i den europæiske menneskerettighedskonvention, jfr. lov nr. 62/1994. 
5. Straffe for promille- og spirituskørsel og berigelsesforbrydelser

Den forvaltningsvej, som nu anvendes, har ført til, at den reelle straf for en bestemt form for forbrydelse har ændret sig meget, uden at domstolene har haft noget med det at gøre. Og det kan diskuteres, om den lovgivende magt har været klar over, at dette ville blive lovens konsekvens. Her taler vi om promille- og spirituskørsel. Tabel 5 viser kriminalitetens art for dem, som afsluttede, afbrød eller var i samfundstjeneste ved udgangen af året i perioden 1995-1999.

Tabel 5. Antal afsluttede, afbrudte og igangvarende samfundstjenestesanktioner, 1995 -1999, fordelt efter kriminalitetens art.

\begin{tabular}{|l|l|l|l|l|l|l|l|l|l|l|l|}
\hline & \multicolumn{2}{|c|}{1995} & \multicolumn{2}{c|}{1996} & \multicolumn{2}{c|}{1997} & \multicolumn{2}{c|}{1998} & \multicolumn{2}{c|}{1999} \\
\hline & Antal & $\%$ & Antal & $\%$ & Antal & $\%$ & Antal & $\%$ & Antal & $\%$ \\
\hline Berig.forbr./dok.falsk & 1 & 5,0 & 1 & 1,7 & 3 & 5,5 & 16 & 17,6 & 11 & 13,9 \\
\hline Trafikforbr./brugstyv. & 16 & 80,0 & 55 & 94,9 & 49 & 89,1 & 61 & 67,0 & 57 & 72,2 \\
\hline Narkotikaforbr. & 0 & 0,0 & 0 & 0,0 & 1 & 1,8 & 5 & 5,5 & 6 & 7,6 \\
\hline Seksualforbr. & 0 & 0,0 & 0 & 0,0 & 0 & 0,0 & 1 & 1,1 & 0 & 0,0 \\
\hline Vold & 0 & 0,0 & 0 & 0,0 & 1 & 1,8 & 5 & 5,5 & 4 & 5,1 \\
\hline Andet & 3 & 15,0 & 2 & 3,4 & 1 & 1,8 & 3 & 3,3 & 1 & 1,3 \\
\hline I alt & 20 & 100 & 58 & 100 & 55 & 100 & 91 & $100^{25}$ & 79 & 100 \\
\hline
\end{tabular}

Som tabel 5 viser, udgør antallet af dømte for overtrædelse af færdselsloven en stor del af dem, som afsoner ved samfundstjeneste. Oftest er der tale om spirituskørsel eller kørsel i frakendelsestiden. I 1998 blev den tremåneders maksimumstraf, som kunne fuldbyrdes med samfundstjeneste, udvidet til seks måneder, jfr. lov nr. 123/1997. Da steg det antal, som afsonede domme ved samfundstjeneste, betydeligt, og det drejer sig især om dømte for berigelsesforbrydelser og dokumentfalsk. ${ }^{26}$ Eftersom man nu kan fuldbyrde op til seks måneders fængselsstraf med samfundstjeneste, har det ført til, at ikke kun korte fængselsstraffe, som domme for færdselslovsovertrædelser, kan afsones med samfundstjeneste, men domme for berigelsesforbrydelser kommer mere og mere ind i billedet.

Det er klart, at den faktuelle straf for spirituskørsel har ændret sig meget. I stedet for ubetingede domme, afsonet i fængsler, afsoner nu en stor del spiritusbilister deres domme ved samfundstjeneste ${ }^{27}$. Denne praksis går imod årtiers retspraksis, som har været, at hvis dommen for promillekørsel er frihedsstraf, er den ubetinget og afsones dermed i fængsel. Det må anses for ret unaturligt, at denne forandring er sket, uden at domstolene har haft nogen indflydelse derpå. Hvis det var den lovgivende magts hensigt at ændre retspraksis, var det blevet omtalt i betænkningen til lovforslaget. Det er derfor klart, at den lovgivende magt ikke har indset, at indførelse af lovbestemmelser om samfundstjeneste ville medføre disse ændringer i strafpraksis for promillekørsel. 
I lov om samfundstjeneste nr. 55/1994 anføres ikke noget om, hvilke forbrydelser der kan føre til afsoning med samfundstjeneste. I § 1 gives der dog et fingerpeg herom, idet der anføres, at dommene kan fuldbyrdes med samfundstjeneste, hvis ikke det går imod almenhedens interesser. Denne paragraf og en bemærkning $\mathrm{i}$ betænkningen indebærer, at samfundstjenesten først og fremmest kan komme på tale $\mathrm{i}$ forbindelse med berigelsesforbrydelser og dokumentfalsk, men ikke i forbindelse med vold, narkotikaforbrydelser eller spirituskørsel, hvor den almenpræventive virkning vejer tungt ved straffens udmåling. Praksis er, som vist ovenfor, siden blevet en anden for spirituskørsel. Det er på sin plads at bemærke, at der måske ikke er noget, der taler imod, at straf for spirituskørsel er samfundstjeneste. Det er på den anden side ikke forvaltningens rolle at beslutte om den slags ændringer, men den lovgivende magts.

I lov nr. 123/1997 findes der et lignende vilkår, som det der var i loven fra 1994, om almenhedens interesse. I betænkningen vedrørende forslag til lov nr. 123/1997 står der intet om forbrydelsens art for dem, der kan få lov til at afsone deres domme med samfundstjeneste. I diskussionen af vurderingen af egnethed til at yde samfundstjeneste kommer man dog ind på dette, idet der står, at karakteren af ansøgerens forbrydelse kan spille en rolle for, hvorvidt han vurderes egnet til samfundstjeneste, og at man skal være forsigtig med at anbefale samfundstjeneste, hvis ansøgeren er dømt for narkotikaforbrydelse, hærværk, eller vold $^{28}$. Spirituskørsel omtales til gengæld slet ikke.

Det er klart, at straf for andre former for forbrydelser, dvs. berigelsesforbrydelser og dokumentfalsk, også er under forandring. Den forandring er dog mere i overensstemmelse med det, som den lovgivende magt har forudset, jfr. omtale af lovforslagene fra 1994 og 1997 ovenfor. Men det er en kendsgerning, at domstolene ikke har del i den sag. Det havde været naturligt, at de dannede praksis for, hvornår samfundstjeneste blev anvendt for berigelsesforbrydelse og dokumentfalsk, og hvornår ikke. Det må også være en besynderlig situation for en dommer at skulle dømme den sigtede til ubetinget fængsel, vel vidende, at det umiddelbart kan ændres til samfundstjeneste, og uden selv at have mulighed for at anvende denne sanktionsmulighed i de tilfælde, hvor det ville være hensigtsmæssigt. Det er også unaturligt, at anklagemyndigheden, som er part i sager, der er under behandling hos domstolene, ingen indflydelse har på, om samfundstjeneste anvendes. I virkeligheden kan hverken anklager eller forsvarer føre sag for domstolene vedrørende anvendelse af samfundstjeneste.

\section{Konklusioner}

De fornyelser inden for sanktionssystemet, der her er behandlet, repræsenterer en stor forbedring. Afsoning hos "Vernd" og i alkohol- og narkotikabehandling er en god måde at bygge bro på mellem fængselsophold og liv i det frie samfund. Der er ingen uenighed om, at beslutning herom hører hjemme hos Fængselsdirektoratet. Samfundstjeneste har også vist sig at fungere godt, og det ser ud 
til, at Fængselsdirektoratets dispositioner i disse sager virker efter hensigten. Det ændrer dog ikke ved, at den vej, som den lovgivende magt er gået ved valg af udformningen af samfundstjeneste, er kritisabel. Det er også bemærkelsesværdigt, at der endnu ikke er lavet en undersøgelse af upartiske, uafhængige parter af fornyelsernes resultater. Så længe en sådan undersøgelse ikke foreligger, er det ikke klart, på hvilket grundlag fremtidsstrategien for kriminalpolitikken i Island skal bygge.

\section{LITTERATUR:}

Althingistidindi (Altingstidende):

1990-91, A-deild (A-del)

1992-93, A-deild (A-del)

1993-94, A-deild (A-del)

1993-94, B-deild (B-del)

1997-98, A-deild (A-del)

1998-99, A-deild (A-del)

Ársskyrsla Fangelsismálastofnunar ríkisins 1995. (Statens fængselsdirektorats årsrapport 1995). 1996. Reykjavík.

Ársskyrsla Fangelsismálastofnunar ríkisins 1996. (Statens fængselsdirektorats årsrapport 1996). 1997. Reykjavík.

Ársskyrsla Fangelsismálastofnunar ríkisins 1997. (Statens fængselsdirektorats årsrapport 1997). 1998. Reykjavík.

Ársskyrsla Fangelsismálastofnunar ríkisins 1998. (Statens fængselsdirektorats årsrapport 1998). 1999. Reykjavík.

Ársskyrsla Fangelsismálastofnunar ríkisins 1999. (Statens fængselsdirektorats årsrapport 1999). 2000. Reykjavík.

Baumer, Eric, Gunnlaugsson, Helgi, Kristinsdóttir, Kristrún og Wright, Richard. 2000. "Skyrsla til íslenskra stjórnvalda um rannsókn á itrekunartídni afbrota." ("Rapport til islandske myndigheder om en undersøgelse af forbrydelsers gentagelsesfrekvens). Reykjavík.

Bragadóttir, Ragnheidur. 1987. "Samfélagsthjónusta sem vidurlagategund." ("Samfundstjeneste som sanktionsform"). Tímarit lögfrædinga, 1. hefti (Juristernes tidsskrift, 1. hæfte). 37: Side $32-45$.

Bragadóttir, Ragnheidur. 1991. "Samfélagsthjónusta." ("Samfundstjeneste”). Úlfljótur, 2. tbl. (Jurastuderendes tidsskrift, nr. 2). XLIV: Side 161-191.

Bragadóttir, Ragnheidur. 2000. "Samfélagsthjónusta - á réttri leid?" ("Samfundstjeneste - på rigtig vej?”) I: Afmælisrit Thórs Vilhjálmssonar (Festskrift til Thór Vilhjálmsson). Side 457-486. Reykjavík: Bókaútgáfa Orators.

Einarsdóttir, Áslaug. 2000. Fangahjálp og medferd fyrir fanga. (Fangehjælp og behandling for fanger). Óbirt kandidatsritgerd í lögfrædi. (Upubliseret kandidatsafhandling i jura).

Eyjólfsson, Thórdur. 1963. "Fésektir.” ("Bøder”). Tímarit lögfrædinga, 2. hefti. (Juristernes tidsskrift, 2. hæfte). 13: Side 49-64.

Gudmundsson, Gudmundur Thór og Hjaltested, Sigridur J. 1996. "Samfélagsthjónusta á Íslandi." ("Samfundstjeneste i Island"). Tímarit lögfrædinga, 2. hefti. (Juristernes tidsskrift, 2. hæfte). 46: Side 107-125.

Handbók - Medferd opinberra mála. (Håndbog - offentlig retspleje). 1992. Dóms- og kirkjumálaráduneytid (Justits- og kirkeministeriet). Reykjavík.

Hjaltested, Sigrídur J. 2000. "Reynslan af samfélagsthjónustu." ("Erfaringen med samfundstjeneste”). Tímarit lögfrædinga, 1. hefti. (Juristernes tidsskrift, 1. hæfte). 50: Side 53-62.

Jóhannesson, Ólafur. 1988. Stjórnskipun Íslands. (Islandsk forfatningsret). Reykjavík: Idunn. 
Jónsson, Helgi I. 1998. "Samfélagsthjónusta - Vidurlög eda fullnustuúrrædi.” ("Samfundstjeneste Sanktion eller fuldbyrdelsesordning”). Tímarit lögfrædinga, 3. hefti. (Juristernes tidsskrift, 3. hæfte). 48: Side 207-214.

Sigurdsson, Jón Fridrik og Baldursson, Erlendur S. 1998. "Áfengis- og fikniefnamedferd í refsivist og endurkoma i fangelsi." ("Alkohol- og narkotikabehandling under afsoning af frihedsstraf og tilbagevenden til fængsel"). Ársskyrsla Fangelsismálastofnunar ríkisins 1997. (Statens fængselsdirektorats årsrapport 1997). Reykjavík.

Skyrsla umbodsmanns Althingis fyrir árid 1996. (Altingets ombudsmands årsrapport 1996). 1997. Reykjavík.

Thórmundsson, Jónatan. 1984. "Réttarstada sakbornings". ("Den sigtedes retsstilling”). Tímarit lögfrædinga, 4. hefti. (Juristernes tidsskrift, 4. hæfte). 34: Side 199-215.

Thórmundsson, Jónatan. 1992. Vidurlög vid afbrotum. (Strafferetlige sanktioner mod forbrydelser). Reykjavík: Bókaútgáfa Orators.

Noter:

1 "Vernd" ("Beskyttelse"), en forening der har hjulpet fanger i snart 40 år.

2 SÁÁ / "Samtök áhugafólks um áfengis- og vímuefnavandann": En interesseorganisation om alkohol- og narkotikaproblemet.

${ }^{3}$ Fængselsdirektoratets årsberetning 1999, s. 14.

${ }^{4}$ Sigurdsson, Jón Fridrik og Baldursson, Erlendur S.: Alkohol- og narkotikabehandling under afsoning af frihedsstraf og tilbagevenden til fængsel. Fængselsdirektoratets årsrapport 1997, s. 56.

${ }^{5}$ Fængselsdirektoratets årsrapport 1999, s. 15.

${ }^{6}$ Altingstidende, 1997-98, A-del, s. 2022.

' Jónsson, Helgi I.: Samfundstjeneste - Sanktion eller fuldbyrdelsesordning. Juristernes tidsskrift 1998, s. 212.

${ }^{8}$ Altingstidende, 1997-98, A-del, s. 2023.

${ }^{9}$ Fængselsdirektoratets årsrapport 1999, s. 18.

${ }^{10}$ Baumer o.fl.: Rapport til islandske myndigheder, s. 40.

"Baumer o.fl.: Rapport til islandske myndigheder, s. 30-31.

${ }^{12}$ Altingstidende, 1998-99, A-del, s. 2272.

${ }^{13}$ Altingstidende, 1998-99, A-del, s. 2273.

${ }^{14}$ Altingstidende, 1998-99, A-del, s. 2273.

${ }^{15}$ Altingstidende, 1992-93, A-del, s. 3835.

${ }^{16}$ Altingstidende, 1992-93, A-del, s. 3835.

${ }^{17}$ Forslaget blev ikke færdigbehandlet i tinget.

${ }^{18}$ Altingstidende, 1990-91, A-del, s. 3094.

${ }^{19}$ Bragadóttir, Ragnheidur: Samfundstjeneste, Úlfljótur 1991, s. 186 og Thórmundsson, Jónatan: Strafferetlige sanktioner mod forbrydelser, 1992, s. 39.

${ }^{20}$ Thórmundsson, Jónatan: Strafferetlige sanktioner mod forbrydelser, 1992, s. 39.

${ }^{21}$ Fængselsdirektoratets årsrapport 1999, s. 27.

${ }^{22}$ Altingstidende, 1998-99, A-del, s. 2272.

${ }^{23}$ Thórmundsson, Jónatan: Strafferetlige sanktioner mod forbrydelser, 1992, s. 62-63.

${ }^{24}$ Jóhannesson, Ólafur: Stjórnskipun Íslands / Islandsk forfatningsret, 1988, s. 391.

${ }^{25}$ Fængselsdirektoratets årsrapport 1999, s. 27.

${ }^{26}$ Fængselsdirektoratets årsrapport 1998, s. 37.

${ }^{27}$ Her taler vi naturligvis ikke om de domme og sanktionsbestemmelser, hvor straffen for promillekørsel er bøde.

${ }^{28}$ Altingstidende, 1997-98, A-del, s. 2018.

\section{Adresse: Det juridiske fakultet}

Islands Universitet

IS-101 Reykjavik

rb@hi.is 